\title{
IAMJ
}

INTERNATIONAL

AYURVEDIC

MEDICAL JOURNAL

Review Article

ISSN: 2320-5091

Impact Factor: 6.719

\section{VAYAHSTHAPANA DASHAKAYA - A REVIEW}

\section{Chathurika L.A.W.J' ${ }^{1}$ Kulathunga R.D.H ${ }^{2}$}

${ }^{1,2}$ Study Unit of Kayachikitsa, Institute of Indigenous Medicine, University of Colombo, Sri Lanka

Corresponding Author: law.jechathu@gmail.com

\section{https://doi.org/10.46607/iamj2609082021}

(Published Online: August 2021)

Open Access

(C) International Ayurvedic Medical Journal, India 2021

Article Received: 15/07/2021 - Peer Reviewed: 17/07/2021 - Accepted for Publication: 18/07/2021

\section{Check for updates}

\begin{abstract}
Vayahsthapana Dashakaya is a medicinal group including herbal plants and organic minerals mentioned in Ayurveda authentic text Charaka Samhita. Amruta, Abhaya, Dhatri, Mukta, Shveta, Jivanti, Atirasa, Mandukaparni, Sthira, and Punarnava are the ten ingredients of Vayahsthapana Dashakaya. The majority of these ingredients contain Rasayana action which is beneficial in anti-ageing treatment. Through Rasayana treatment, which is also known as a promotive treatment, one can attain effects including longevity, youthful age, excellent lustre, and complexion. This study was focused to analyze the Pharmacodynamic, Pharmacokinetic and Pharmacological potentials of Vayahsthapana Dashakaya and their action in anti-ageing treatment. The contents were collected from authentic Ayurveda texts, monographs, dictionaries, websites, and research articles. Results of the study revealed that $80 \%$ possibility of Deepana action, Rasayana action (70\%), Balya (50\%), Medhya (50\%), Hridya (40\%), Vrushya (20\%), and Brunhana (20\%) were present as prominent actions of Vayahsthapana dashakaya which are beneficial in delaying the ageing process and its ill effects.
\end{abstract}

Keywords: Ayurveda, Rasayana, Vayahsthapana Dashakaya, Anti-ageing, 


\section{INTRODUCTION}

Vayahsthapana Dashakaya is a collection of ten Drava (Ingredients) which is found in Charaka Samhita Sutrasthana, Shad virechana shatashriteeya adhyaya. [1] Vayahsthapana Dashakaya or Vayahsthapana Gana is one group among the fifty groups mentioned in this chapter. अम्मुताऽभयाधात्रीमुक्ताश्वेताजीवन्त्यतिरसामणदूकपर्णीस्थिरा पुनर्नवा इति दशेमानि वयः:स्थापनानि भवन्ति Ca.Su. 4/18

[1] Amruta (Tinospora cordifolia Miers), Abhaya (Terminalia chebula), Dhatri (Emblica Officinalis Gaertn.), Mukta (Pearl), Shveta (white variety of Clitoria ternatea Linn.), Jivanti (Leptadenia reticulate), Atirasa (Asparagus racemosus Willd.), Mandukaparni (Centella asiatica Urban.), Sthira (Desmodium gangeticum), and Punarnava (Boerhavia diffusa Linn.) are included in Vayahsthapana Dashakaya. ${ }^{[1]}$ Among this pearl is considered as an organic mineral mixture, not a true mineral. [2], [3]

Acharya Chakrapani commented Vayahsthapana asवयस्तरुणं स्थापयतीति वयःस्थापनम् Ayurveda deepika on Ca. Su.4/18 ${ }^{[4]}$ The action which stabilizes the age of the young is called Vayahsthapana.

Vayahsthapana action can be gained through $R a$ sayana action. According to Charaka acharya benefits of Rasayana treatment includes anti-ageing action. Deerga Ayu (Long life), Smruti (better recollection) Medha (increased intellect), Arogya (healthy body and mind) Tharuna vayah (youthfulness), good colour \& complexion, good voice, an abundance of body and sense organ strength, acceptance to speech and increased lustre are achieved through Rasayana. ${ }^{[5]}$ Also, it has been mentioned that method of $R a$ sayana treatment is like Amruta which is beneficial to gods, having incomprehensible miraculous effects, promotes life span (Ayushya), provides health, sustains (Youthful) age, removes sleepiness, drowsiness, exertion, exhaustion, lassitude, and debility, restores the equilibrium of vata, kapha and pitta, brings stability, alleviates laxity of muscles, kindles internal fire, and produces excellent lustre, complexion and voice. ${ }^{[5]-~}$ [7]

In humans, ageing represents the accumulation of changes in a human being over time and can encompass physical, psychological, and social changes. Ageing increases the risk of human diseases: of the roughly 150,000 people who die each day across the globe, about two-thirds die from age-related causes. ${ }^{[8]}$ As people age, they are more likely to experience several conditions at the same time. Older age is also characterized by the emergence of several complex health states that tend to occur only later in life and that do not fall into discrete disease categories. These are commonly called geriatric syndromes. Between 2015 and 2050, the proportion of the world's population over 60 years will nearly double from $12 \%$ to $22 \%$. ${ }^{[8]}$ The pace of population ageing is much faster than in the past and ageing increases the risk of diseases. ${ }^{[9]}$ Hence study has been focused to find out Pharmacodynamic, Pharmacokinetic and Pharmacological potentials of Vayahsthapana Dashakaya and analyzing the action of Vayahsthapana Dashakaya in anti-ageing treatment.

\section{Methodology}

Information on Vahasthapana dashakaya was gathered using classical Ayurveda texts and the Pharmacological study of medicinal plants in Vayahsthapana dashakaya was discussed through various sources including books, monographs, research articles and websites. Finally analyzed the gathered data of $\mathrm{Va}$ hasthapana dashakaya and evaluated their effectiveness in anti-ageing treatment. 


\section{RESULTS}

Table 1: Pharmacodynamic properties of Vayahsthapana Dashkaya

\begin{tabular}{|l|l|l|l|l|l|}
\hline Name of the dravya & Rasa & Guna & Vipaka & Veerya & Dosha Karma \\
\hline Amruta $^{[10],[12]-[16]}$ & Tikta, Katu, Kashaya & Snigdha, Laghu, Mrudu & Madhura & Ushna & Tridoshaghna \\
\hline Abhaya $^{[10],[12]-[16]}$ & Kashaya pradhana pancharasa & Ruksha, Laghu & Madhura & Ushna & Tridoshahara \\
\hline Dhatri $^{[10],[12]-[16]}$ & $\begin{array}{l}\text { Amla pradhana pancharasa } \\
\text { without lavana rasa }\end{array}$ & Laghu, Ruksha & Madhura & Shita & Tridoshaghna \\
\hline Mukta $^{[11],[17]}$ & Madhura & Laghu & Madhura & Shita & Tridosha shamana \\
\hline Shweta $^{[10],[12]-[16]}$ & Tikta, Katu, Kashaya & Tikshna, Laghu & Katu & Shita & Tridoshaghna \\
\hline Jivanti $^{[10],[12]-[16]}$ & Madhura & Laghu, Snigdha & Madhura & Shita & Tridoshaghna \\
\hline Atirasa $^{[10],[12]-[16]}$ & Madhura, Tikta & Guru, Snigdha, Mrudu & Madhura & Shita & Vata-Pittaghna \\
\hline Mandukaparni $^{[10],[12]-[16]}$ & Tikta, Kashaya, Madhura & Laghu & Madhura & Shita & Tridosha shamaka \\
\hline Sthira ${ }^{[10],[12]-[16]}$ & Madhura & Guru, Snigdha & Madhura & Shita & Tridoshaghna \\
\hline Punarnava $^{[10],[12]-[16]}$ & Madhura, Tikta, Kashaya & Laghu, Ruksha, Sara & Katu & Ushna & Tridoshaghna \\
\hline
\end{tabular}

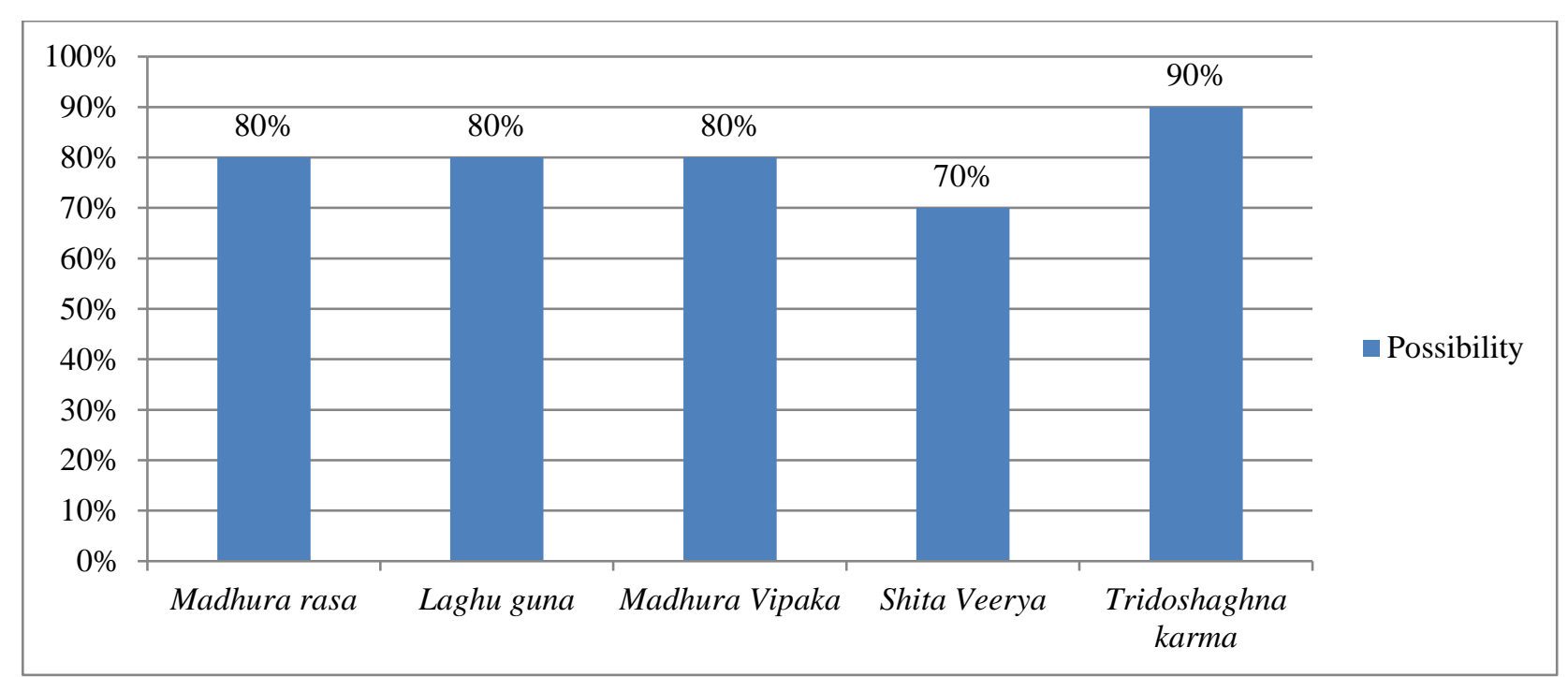

Figure 1: Percentage-wise distribution of possibilities of Pharmacodynamic properties of Vayahsthapana Dashakaya Figure 1 shows, that Madhura rasa (80\%), Laghu guna (80\%), Madhura vipaka (80\%), Shita veerya (70\%) and Tridoshaghna karma (90\%) are present in Vayahsthapana dashakaya.

Table 2: Pharmacokinetic Properties of Vayahsthapana Dashakaya

\begin{tabular}{|c|c|}
\hline Name of the dravya & Karma \\
\hline Amruta ${ }^{[10],[12]-[16]}$ & Dipana, Pachana, Anulomana, Balya, Hridya, Rasayana, Raktaprasadana, Sangrahini, Vedanasthapana \\
\hline Abhaya ${ }^{[10],[12]-[16]}$ & Dipana, Pachana, Medhya, Rasayana, Chakshushya, Ayushya, Brunhana, Anulomana, Vedanasthapana \\
\hline Dhatri ${ }^{[10],[12]-[16]}$ & Agnidipana, Amapachana, Anulomana, Prajasthapana, Vrushya, Rasayana, Medhya, Balya. \\
\hline Mukta ${ }^{[11],[17]}$ & Lekhana, Medhya, Nadibalya, Dipana, Hridya, Jeevaniya, Shothahara, Kaphanissaraka, Chakshushya \\
\hline Shweta ${ }^{[10],[12]-[16]}$ & Dipana, Pachana, Krumighna, Vishapaha \\
\hline Jivanti $^{[10],[12]-[16]}$ & $\begin{array}{l}\text { Balya, Rasayana, Snehana, Vatanulomana, Grahi, Raktapittashamaka, Shukrasthambhana, Mutrala, } \\
\text { Chakshushya }\end{array}$ \\
\hline Atirasa $[10],[12]-[16]$ & Balya, Dipana, Shoolaghna, Brunhana, Rasayana, Shukravruddhikara, Medhya, Hridya, Vrushya, Shothahara \\
\hline $\begin{array}{l}\text { Mandukaparni }[10],[12]- \\
{[16]}\end{array}$ & $\begin{array}{l}\text { Hridya, Rasayana, Vayasthapana, Raktaprasadana, Raktastambhana, Ampachana, Medhya, Ayushya, Svarya, } \\
\text { Smruthiprasada }\end{array}$ \\
\hline Sthira ${ }^{[10],[12]-[16]}$ & Dipana, Pachana, Anulomana, Brunhana, Mutrala, Rasayana, Balya, Vishahara \\
\hline Punarnava ${ }^{[10],[12]-[16]}$ & Dipana, Anulomana, Rechana, Mutrala, Shothaghna, Vayahsthapana, Pandughna, Shophahara, Grahi \\
\hline
\end{tabular}




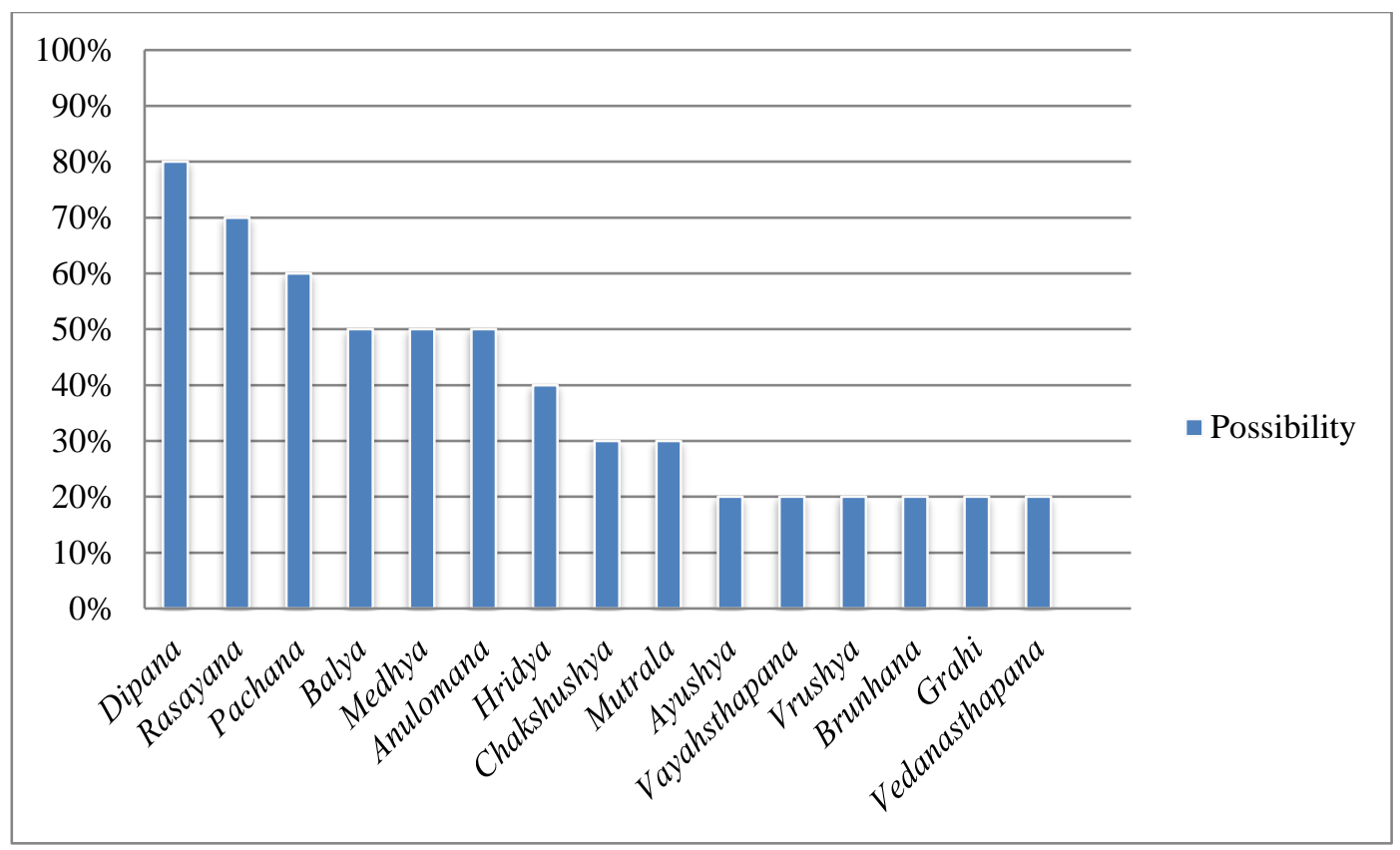

Figure 2: Percentage-wise distribution of possibilities of Pharmacokinetic properties of Vayahsthapana Dashakaya Figure 2 shows Dipana (80\%) and Rasayana (70\%) as prominent actions found in Vayahsthapana dashakaya.

Table 3: Pharmacological Potentials of Vayahsthapana Dashakaya

\begin{tabular}{|c|c|}
\hline $\begin{array}{l}\text { Name of the } \\
\text { Dravya }\end{array}$ & Pharmacological Potentials \\
\hline Amruta & $\begin{array}{l}\text { Anti-inflammatory, Diuretic, Anthelmintic, Nerve tonic, Antioxidant, Antimicrobial, Anti-toxic effects, Anti diabetic, } \\
\text { Anti stress activity, Cholagogue, Detoxicant, Immune tonic, Hypolipidemic effect, Prevent skeletal muscle atrophy, } \\
\text { Hepato protective and Immunomodulating activities [12], [14], [15], [16], [20], [23], [38], [39] }\end{array}$ \\
\hline Abhaya & $\begin{array}{l}\text { Laxative, Astringent, Anthelmintic, Nerve tonic, Expectorant, Antioxidant, Immunomodulatory, Antibacterial, Antifun- } \\
\text { gal, Antiviral, Antiprotozoal, Hepatoprotective, Cardioprotective, Cytoprotective, Anti-diabetic, Renoprotective, Anti- } \\
\text { inflammatory, Hypolipidemic, Hypocholesterolemic, Gastrointestinal motility, Antiulcer, Antispasmodic, Purgative and } \\
\text { Antiallergic activities [12], [14], [15], [16], [20], [28] }\end{array}$ \\
\hline Dhatri & $\begin{array}{l}\text { Antacid, Anti-inflammatory, Antipyretic, Digestive, Laxative, Hepatoprotective, Astringent, Haemostatic, Antioxidant, } \\
\text { Cardio tonic, Immunomodulatory, Anti-cancer, Nutritive, Ophthalmic and Aphrodisiac activity [12], [14], [15], [16], [20], [35], [36] }\end{array}$ \\
\hline Mukta & Antipyretic, Anti-ulcer, Brain tonic, and Antihypertensive activity ${ }^{[17],[18],[21],[30],[31],}$ \\
\hline Shweta & $\begin{array}{l}\text { Nootropic, Anti-inflammatory, Analgesic, Antipyretic, Anti-diabetic, Antioxidant, Anthelmintic, Hepatoprotective, } \\
\text { Antimicrobial and Immunomodulatory effect }{ }^{[12],[14],[15],[16],[20],[34],[37],[40]}\end{array}$ \\
\hline Jivanti & $\begin{array}{l}\text { Anti - abortifacient, Anti-anaphylactic, Antidepressant, Anti-epileptic, Antimicrobial, Antitumor/in vitro cytotoxic, } \\
\text { Antioxidant, Antipyretic, Analgesic, Anti-inflammatory, Antiulcer, Anxiolytic, Cardioprotective, Diuretic, Galacto- } \\
\text { gogue, Hepatoprotective, Immunomodulatory and Rejuvenating activities [12], [14], [15], [16], [20], [26], [41] }\end{array}$ \\
\hline Atirasa & $\begin{array}{l}\text { Demulcent, Galactagogue, Anti-inflammatory, Aphrodisiac, Female Reproductive Tonic, Spermatogenic, Antihaemor- } \\
\text { rhagic, Expectorant, Adaptogen, Irmmunomodulatoy, Antibacterial, and Antioxidant effects [12], [14], [15], [16], [20], [33] }\end{array}$ \\
\hline Mandukaparni & 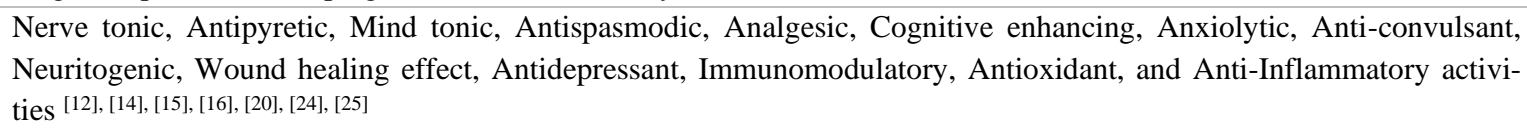 \\
\hline Sthira & $\begin{array}{l}\text { Anti-inflammatory, Analgesic activity, Antioxidant, Hypocholestrolemic, Anti-amnesic activities, Anti-diabetic, Anti- } \\
\text { pyretic, Cardiovascular effects, Anti-ulcer, Anti- bacterial and Wound healing activity [12], [14], [15], [16], [20], [29], [32] }\end{array}$ \\
\hline Punarnava & $\begin{array}{l}\text { Diuretic, Lithagogue, Cardiotonic, Immunomodulatory, Immunosuppressive, Anticancer, Antidiabetic and Hypoglyce- } \\
\text { mic, Antifibrinolytic, Anti-Inflammatory, Hepatoprotective, Antimicrobial, Antioxidant and Anticonvulsant activities } \\
{[12],[14],[15],[16],[20],[27]}\end{array}$ \\
\hline
\end{tabular}




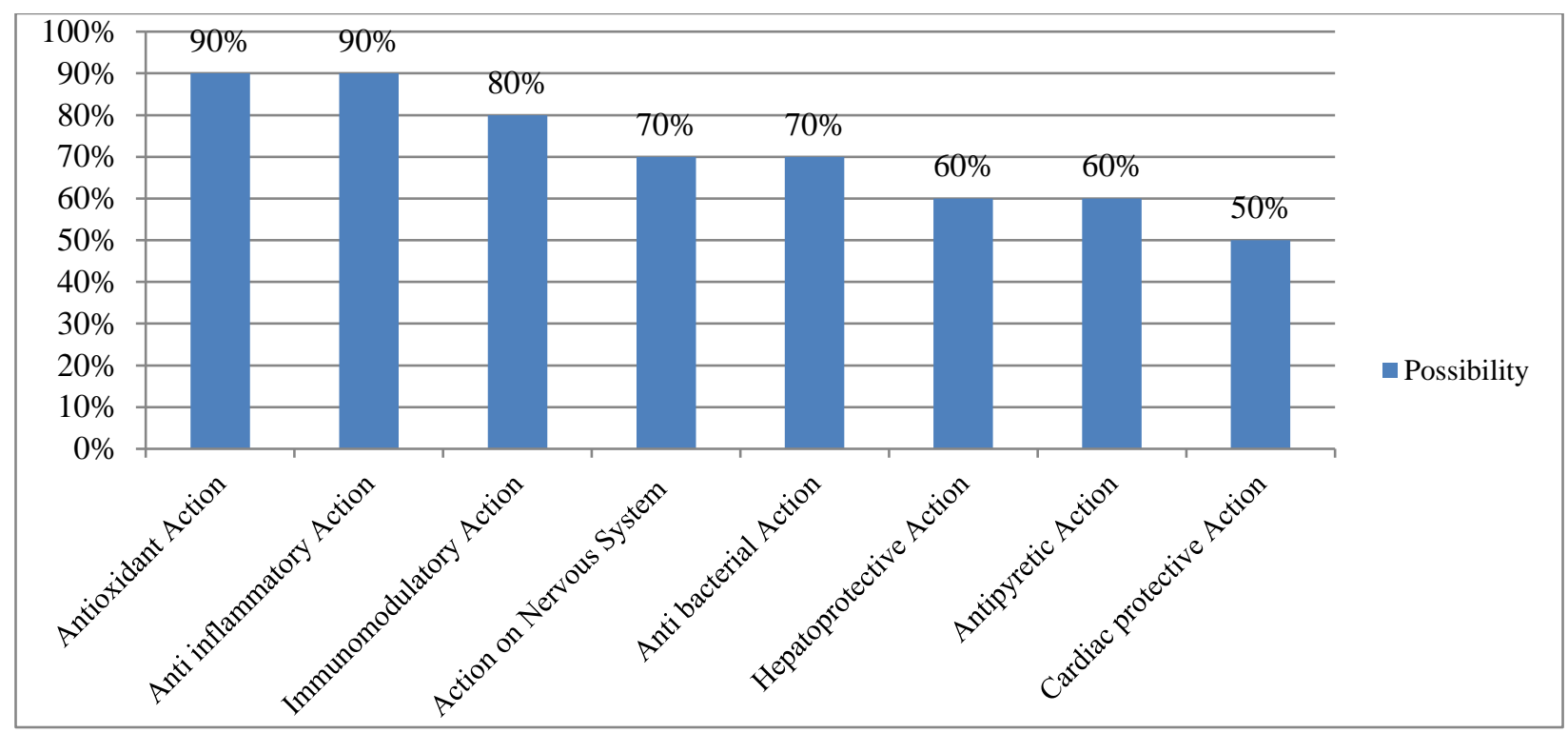

Figure 3: Percentage-wise distribution of possibilities of relevant Pharmacological Potentials of Vayahsthapana Dashakaya Figure 3 revealed that the highest percentages of Antioxidant, Anti-inflammatory and Immunomodulatory actions are present in Vayahsthapana Dashakaya.

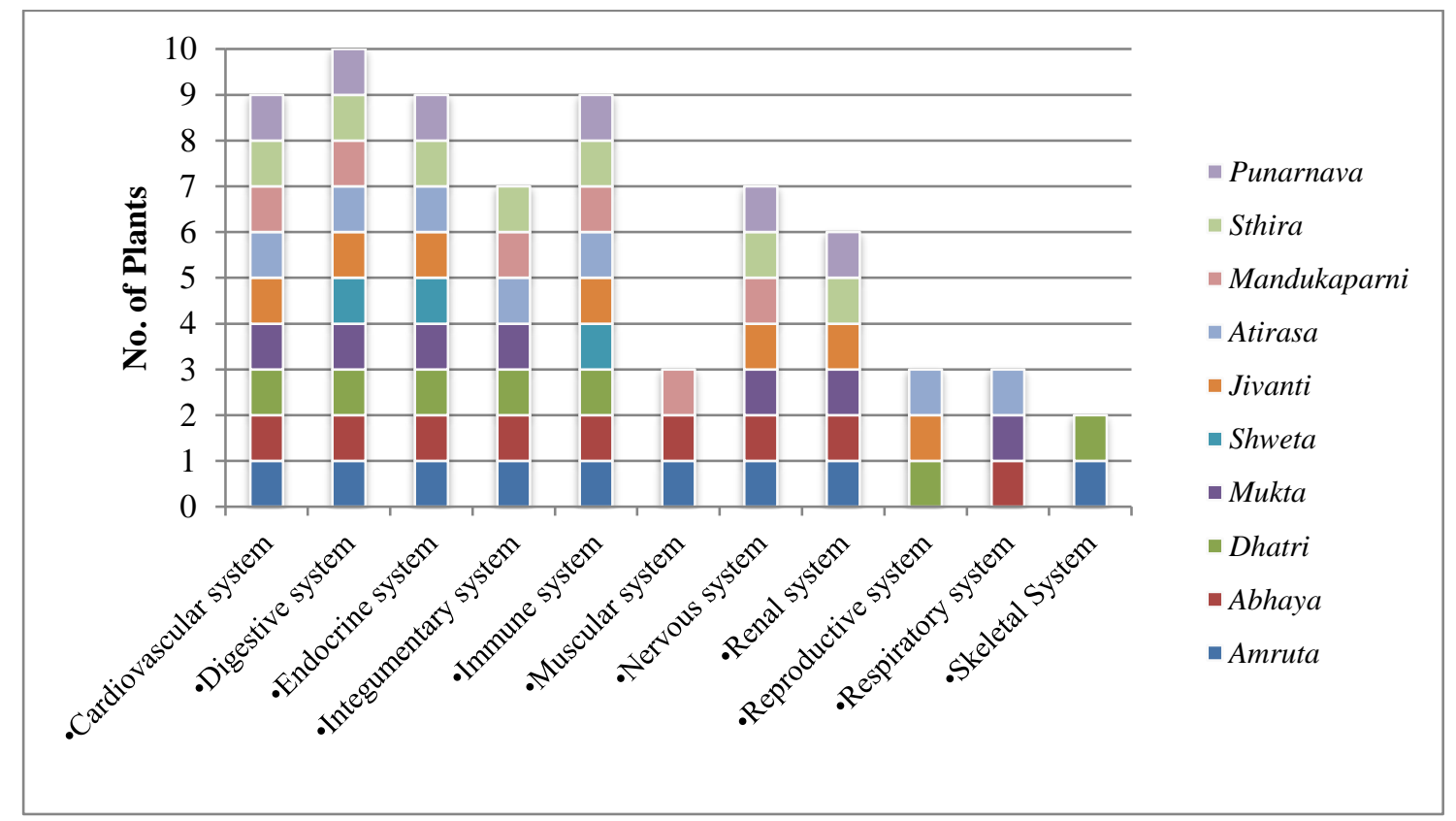

Figure 4: Distribution of No. of plants which show action on specific systems of the human body Above figure No. 4 interprets that the ingredients of Vayahsthapana dashakaya act on the systems of the human body.

Almost all the ingredients act on the Digestive system (100\%) and nine of the ingredients act on the Cardiovascular, Endocrine, and Immune systems.

\section{DISCUSSION}

Ageing is an inevitable process that everyone must face. Vata dosha is dominant in old age and sapta dhatu are in deficient condition. ${ }^{[5]}$ Rasayana is that 
by which one attains rasadi dhatus with affluence; or the means of attainment of longevity, strength, energy, and firmness and sustain youthfulness as effects of rasa, virya and vipaka located in Rasayana. It promotes, sustains, or generates dhatus and qualities. [6] Among pharmacodynamic properties of vayahsthapana dashakaya, the majority of the ingredients contain Madhura rasa, Laghu guna, Madhura Vipaka, Sheeta Veerya and Tridoshaghna properties (Fig.1). As a whole compound, ingredients of Vayahsthapana dashakaya act to pacify tridosha, dhatu and mala of the human body, through these properties. There is an $80 \%$ possibility of Deepana action, $70 \%$ possibility of Rasayana action, Balya (50\%), Medhya (50\%), Hridya (40\%), Vrushya (20\%), and Brunhana (20\%) among pharmacokinetic properties (Fig. 2). These properties act on various systems of the human body, repairing the processes that are affected due to ageing. Among these, through rasayana action one can gain longevity. ${ }^{[5]}$ Seven ingredients of Vayahsthapana Dashakaya contain $R a$ sayana action according to figure 2 . If a person takes these herbal drugs regularly, he can maintain the youth for a longer time. ${ }^{[5]-[7]}$ Also various medicinal recipes include ingredients of Vayahsthapana dashakaya mentioned in Caraka Samhita Rasayana chapter which proves that these ingredients help to maintain youthful age. According to research papers, $R a$ sayana action can be interpreted with Immunomodulatory action, in the modern aspect, which prevents recurrent infection and expels the damaged cells, as well as adaptogenic action and anti-ageing action. ${ }^{[12]}$ There is a $90 \%$ of possibility of Antioxidant activity, Anti-inflammatory action (90\%), Immunomodulatory effects (80\%), Nervous system effects (70\%), Hepatoprotective action (60\%), and Cardiac effects (50\%) among pharmacological potentials of Vayahsthapana Dashakaya which protect the human body from ill effects of ageing (Fig. 3). Ageing results due to various factors including oxidative damage, damages to cells due to heterogeneity, imperfectness, and infidelity of biological systems, programmed cell death and more factors that are still not known. ${ }^{[8],[43]}$ According to these theories ageing affects almost all the systems of the human body. Almost all the ingredients of Vayahsthapana Dashakaya act on the digestive system (Fig. 4). In Ayurveda, Agni plays the main role in maintaining health. So, by acting on the digestive system Vayahsthapana Dashakaya helps in digestion and metabolism by maintaining the proper functioning of Agni which leads to proper nourishment of dhatus which in turn fulfil Rasayana action. ${ }^{[5]}$ Also, figure No.4 interprets that all the ingredients of Vayahsthapana Dashakaya collectively act on all the systems of the human body and prevent structural and functional changes occur due to ageing.

\section{CONCLUSION}

All the pharmacodynamic and pharmacokinetic properties collectively pacify Dosha, Dhatu, Mala and maintain the equilibrium of the body which helps to stabilize the process of ageing. The pharmacological potentials of Vayahsthapana Dashakaya help to prevent damages and protect the human body from ageing disorders. It can be concluded that Vayahsthapana Dashakaya is effective in anti-ageing treatment.

\section{REFERENCES}

1. Sharma P. V, Sharma R, Dash B. Caraka saṃhitā. Volume I, Sutrasthana, 4th Chapter, Varanasi: Chaukhambha Orientalia; 2014. 101p

2. Pearl [Internet]. 2021 [cited 23 April 2021]. Available from: https://www.mindat.org/min-42674.htm

3. PEARL, a composite of Aragonite and conchiolin. 2021 [cited 23 April 2021]. Available from: http://www.galleries.com/minerals/gemstone/pearl/pea rl.htm

4. Gaur. A STUDY ON "AMALAKAMVAYAHSTHAPANANAM" (THE BEST REJUVENATOR). UNIQUE JOURNAL OF AYURVEDIC AND HERBAL MEDICINES [Internet]. 2021 [cited 18 April 2021];02(01):18-21. Available from: http://ujconline.net/wp-content/uploads/2013/09/5UJAHM-1480-RV.pdf

5. Sharma P. V, Caraka Saṃhitā. Volume II, Chikitsasthana, 1st Chapter, Varanasi: Chaukhambha Orientalia; 2014. 3-4 p, 13p

6. Sharma P.V, Susruta Samhita. Vol. II, 27th Chapter, Varanasi: Chaukhambha Visvabharati; 2010. 526-530 p. 
7. Sharma P.V, Susruta Samhita. Vol. II, 28th Chapter, Varanasi: Chaukhambha Visvabharati; 2010. 531-537 p.

8. Ageing - Wikipedia [Internet]. En.wikipedia.org. 2021 [cited 16 April 2021]. Available from: https://en.wikipedia.org/wiki/Ageing\#Definitions

9. Ageing and health [Internet]. Who.int. 2021 [cited 4 April 2021]. Available from: https://www.who.int/news-room/factsheets/detail/ageing-and-health

10. Sitaram B. S, Chunekar K.C, Bhavaprakasha. Volume I, 6th Chapter, Varanasi: Chaukhambha Orientalia; 2018. 130-134,135-136, 229-230, 235-236, 240-241, 277-278, 290-291, 306-307 p.

11. Satpute D.A, Rasaratna Samuchchaya, Vol.I, Chapter IV, Mysore: Chetan Prakashana; 1992. 35, 39 p

12. Gunjan M. Chandurkar, Archana S. Dachewar. A review - role of Vayahsthapan Gana Mahakashaya in ageing/geriatrics Ayurline: International Journal of Research in Indian Medicine 2019; 3(4): 1 - 7

13. Ojha J.K, A Handbook of Dravya Guna. Delhi: Chaukhambha Sanskrit Pratishthan; 2004. 399-400 p.

14. Prakash S, Singh A, Dwivedi K, Sonkar N. Role of Vayahsthapana drugs in Prevention and Management of Ageing [Internet]. Biomedical and Pharmacology Journal. 2021 [cited 3 April 2021]. Available from: https://biomedpharmajournal.org/vol3no1/role-ofvayahsthapana-drugs-in-prevention-and-managementof-ageing

15. Sharma S, Sharma R, Rath S. IMPORTANCE OF VAYASTHAPANA-MAHAKASHAYA DRUGS WSR TO ITS POTENTIAL USES IN GERIATRIC CARE. WORLD JOURNAL OF PHARMACY AND PHARMACEUTICAL SCIENCES [Internet]. 2021 [cited 26 April 2021];10(2):715-723. Available from: https://storage.googleapis.com/journaluploads/wjpps/article_issue/1612774575.pdf

16. Sebestian P, AYURVEDIC MEDICINE the Principles of Traditional Practice., Part Two, London: Jessica Kingsley Publishers; 2013. 126,187,189, 194, 246, $271 \mathrm{p}$

17. Prakash Adhav, K., \& H. Lahare, K. (2015). PREPARATION OF MUKTA BHASMA BY TWO DIFFERENT METHODS AND ITS COMPARATIVE ANALYTICAL STUDY. International Journal of Ayurveda and Pharma Research, 2(5). Retrieved from https://ijapr.in/index.php/ijapr/article/view/218

18. Suman lata, Rudrambika S. Biradar. PharmaceuticoAnalytical Study of Mukta Bhasma Prepared in
Godugdha. International Journal of Ayurveda and Pharma Research. 2015;3(7):56-60.

19. Pal S. The Ayurvedic Bhasma: The Ancient Science of Nanomedicine. Recent Patents on Nanomedicine [Internet]. 2015 [cited 26 April 2021];5(1):12-18. Available from: https://www.ncbi.nlm.nih.gov/pmc/articles/PMC3960 793/

20. Shah JS, Goyal RK. Investigation of Neuropsychopharmacological Effects of a Polyherbal Formulation on the Learning and Memory Process in Rats J Young Pharm. 2011 Apr-Jun; 3(2): 119-124. DOI: 10.4103/0975-1483.80296

21. VS G, MK S. A Review on Mukta Ancient Drug. JOURNAL OF PHARMACY AND EXPERIMENTAL MEDICINE [Internet]. 2021 [cited 18 April 2021];01(01):1-4. Available from: https://bostonsciencepublishing.us/scienceworld/articlepdf/jpem102.pdf

22. Satadru Palbag, Kuntal Pal, Dhiman Saha, M.K. Nandi, B.K. De, D.N.S. Gautam. Pharmaceutics, ethnopharmacology, chemistry and pharmacology of Ayurvedic marine drugs: A review. Int. J. Res. Ayurveda Pharm. 2013;4(3):437-442

23. 23. Sharma P, Dwivedee B, Bisht D, Dash A, Kumar D. The chemical constituents and diverse pharmacological importance of Tinospora cordifolia. Heliyon [Internet]. 2019 [cited 24 April 2021];5(9):e02437. Available from: https://www.ncbi.nlm.nih.gov/pmc/articles/PMC6827 274/

24. Gray N, Alcazar Magana A, Lak P, Wright K, Quinn $\mathrm{J}$, Stevens $\mathrm{J}$ et al. Centella asiatica: phytochemistry and mechanisms of neuroprotection and cognitive enhancement. Phytochemistry Reviews [Internet]. 2017 [cited 25 April 2021];17(1):161-194. Available from: https://www.ncbi.nlm.nih.gov/pmc/articles/PMC6857 646

25. Gray N, Alcazar Magana A, Lak P, Wright K, Quinn $\mathrm{J}$, Stevens J et al. Pharmacological Review on Centella asiatica: A Potential Herbal Cure-all, Indian Journal of Pharmaceutical Sciences [Internet]. 2010 [cited 25 April 2021];72(5):546-556 Available from: https://www.ncbi.nlm.nih.gov/pmc/articles/PMC3116 297/

26. Mohanty S, Swamy M, Sinniah U, Anuradha M. Leptadenia reticulata (Retz.) Wight \& Arn. (Jivanti): Botanical, Agronomical, Phytochemical, Pharmacological, and Biotechnological Aspects. Molecules [Inter- 
net]. 2017 [cited 21 April 2021];22(6):1019. Available from:

https://www.ncbi.nlm.nih.gov/pmc/articles/PMC6152 761/

27. Mishra S, Aeri V, Gaur P.K, Jachak S.M, Phytochemical, Therapeutic, and Ethnopharmacological Overview for a Traditionally Important Herb: Boerhavia diffusa Linn.: [Internet]. 2014[ cited 21 April 2021]: 808302. Available from: https://www.ncbi.nlm.nih.gov/pmc/articles/PMC4053 255/

28. Bag A. Bhattacharyya S.K, Chattopadhyay R.R. The development of Terminalia chebula Retz. (Combretaceae) in clinical research.: [Internet]. 2013 Mar; 3(3): 244-252. Available from: https://www.ncbi.nlm.nih.gov/pmc/articles/PMC3631 $759 /$

29. Vaghela B, Buddhadev S, Shukla L. Pharmacological activities of Desmodium gangeticum: An overview. An Int J Pharm Sci 2013; 4:264-78. Available from: https://www.researchgate.net/publication/318308121_ PHARMACOLOGI-

\section{CAL_ACTIVITIES_OF_DESMODIUM_GANGETI CUM_AN_OVERVIEW}

30. Singh, S.K, Bhat, S.A, Hanif, K, Ahmad, I, Arun, J. A Study on the Antihypertensive Activity of MuktaVati (Ayurvedic Preparation) In Deoxycorticosterone acetate (DOCA) salt Induced Hypertension in Rats. Indian Journal of Research in Pharmacy and Biotechnology. 2014;2(3): 1219-1224.Available from: https://ijrpb.com/issues/Volume\%202_Issue\%203/ijrp b\%202(3)\%2012\%20sandeep\%20kumar\%20singh\%2 01219-1224.pdf

31. Lata, S., \& S.Biradar, R. (2015). PHARMACEUTICAL-ANALYTICAL STUDY OF MUKTA BHASMA PREPARED IN GODUGDHA. International Journal of Ayurveda and Pharma Research, 3(7). Retrieved from https://ijapr.in/index.php/ijapr/article/view/115

32. Globinmed. Desmodium gangeticum (L) DC. [Online]. Available from: https://globinmed.com/index.php?option=com_conten t\&view=article\&id=105859: desmodium- gangeticum1 -dc\&catid $=286 \&$ Itemid $=357 \quad[$ Accessed 5 April 2021].

33. Alok S, Jain SK, Verma A, Kumar M, Mahor A, Sabharwal M. Plant profile, phytochemistry and pharmacology of Asparagus racemosus (Shatavari): A re- view. Asian Pac J Trop Dis. 2013;3(3):242-251., Available from: https://www.ncbi.nlm.nih.gov/pmc/articles/PMC4027 291/

34. Kshirsagar S, Thakur A.S, Kshirsagar J, Immunomodulatory and antioxidative properties of Clitoria ternatea, International Journal of Plant Sciences, Internat. J. Plant Sci., 10 (2): 158-162.Available from: http://researchjournal.co.in/upload/assignments/10_15 8-162.pdf

35. S. Madhuri, G. Pandey, K.S. Verma, Antioxidant, immunomodulatory and anticancer activities of Emblica officinalis: an overview, Int. Res. J. Pharm. 2 (2011) 38-42. Available from: https://www.researchgate.net/publication/270220195_ Antioxi-

dant_immunomodulatory_and_anticancer_activities_o f_Emblica_officinalis_An_overview

36. Penolazzi L, Lampronti I, Borgatti M, Khan MT, Zennaro M, Piva R, Gambari R. Induction of apoptosis of human primary osteoclasts treated with extracts from the medicinal plant Emblica officinalis. BMC Complement Altern Med. 2008 Oct 30; 8:59. Available from:

https://www.ncbi.nlm.nih.gov/pmc/articles/PMC2587 459/ - dhatri osteoarthritis

37. Nithianantham K, Shyamala M, Chen Y, Latha LY, Jothy SL, Sasidharan S. Hepatoprotective potential of Clitoria ternatea leaf extract against paracetamolinduced damage in mice. Molecules. 2011;16(12):10134-10145. Available from: https://www.ncbi.nlm.nih.gov/pmc/articles/PMC6264 671/

38. Sannegowda KM, Venkatesha SH, Moudgil KD. Tinospora cordifolia inhibits autoimmune arthritis by regulating key immune mediators of inflammation and bone damage. Int J Immunopathol Pharmacol. 2015 Dec;28(4):521-31. Available from: https://pubmed.ncbi.nlm.nih.gov/26467057/

39. 39. Sharma B, Dutt V, Kaur N, Mittal A, Dabur R. Tinospora cordifolia protects from skeletal muscle atrophy by alleviating oxidative stress and inflammation induced by sciatic denervation. J Ethnopharmacol. 2020 May 23;254:112720. Available from: https://pubmed.ncbi.nlm.nih.gov/32114167/

40. Maneesai P, Iampanichakul M, Chaihongsa N, Poasakate A, Potue P, Rattanakanokchai S, Bunbupha S, Chiangsaen P, Pakdeechote P. Butterfly Pea Flower (Clitoria ternatea Linn.) Extract Ameliorates Cardio- 
vascular Dysfunction and Oxidative Stress in Nitric Oxide-Deficient Hypertensive Rats. 2021; 10(4): 523.Available from: https://www.ncbi.nlm.nih.gov/pmc/articles/PMC6546 959

41. Mohanty S.K, Swamy M.K, Sinniah U.R, Anuradha M, Leptadenia reticulata (Retz.) Wight \& Arn. (Jivanti): Botanical, Agronomical, Phytochemical, Pharmacological, and Biotechnological Aspects, 2017; 22(6): $1019 . \quad$ Available from: https://www.ncbi.nlm.nih.gov/pmc/articles/PMC6152 761/

42. Fusco D, Colloca G, Monaco M.R.L, Cesar M, Effects of antioxidant supplementation on the ageing process, 2007; 2(3): 377-387Available from: https://www.ncbi.nlm.nih.gov/pmc/articles/PMC2685 $276 /$

43. 4Gladyshev V.N, The Free Radical Theory of Aging Is Dead. Long Live the Damage Theory, Antioxidants \& Redox Signaling; 2014; 20(4): 727-731. Available from:

https://www.ncbi.nlm.nih.gov/pmc/articles/PMC3901 $353 /$

\section{Source of Support: Nil \\ Conflict of Interest: None Declared}

How to cite this URL: Chathurika L.A.W.J \& Kulathunga R.D.H: Vayahsthapana Dashakaya - A Review. International Ayurvedic Medical Journal \{online\} 2021 \{cited August 2021\} Available from: http://www.iamj.in/posts/images/upload/1759_1767.pdf 